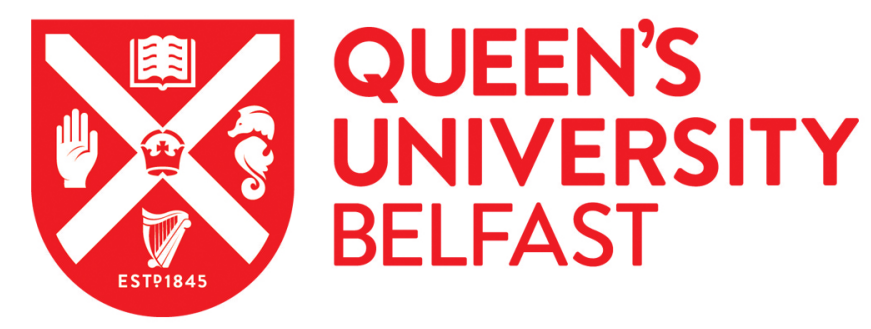

\title{
Influence of early stages of arbuscular mycorrhiza on uptake of zinc and phosphorus by red clover from a low-phosphorus soil ameded with zinc and phosphorus
}

Bi, Y. L., Li, X. L., \& Christie, P. (2003). Influence of early stages of arbuscular mycorrhiza on uptake of zinc and phosphorus by red clover from a low-phosphorus soil ameded with zinc and phosphorus. Chemosphere, 50(6)(6), 831-837. https://doi.org/10.1016/S0045-6535(02)00227-8

Published in:

Chemosphere

Queen's University Belfast - Research Portal:

Link to publication record in Queen's University Belfast Research Portal

\section{General rights}

Copyright for the publications made accessible via the Queen's University Belfast Research Portal is retained by the author(s) and / or other copyright owners and it is a condition of accessing these publications that users recognise and abide by the legal requirements associated with these rights.

Take down policy

The Research Portal is Queen's institutional repository that provides access to Queen's research output. Every effort has been made to ensure that content in the Research Portal does not infringe any person's rights, or applicable UK laws. If you discover content in the Research Portal that you believe breaches copyright or violates any law, please contact openaccess@qub.ac.uk. 


\title{
Influence of early stages of arbuscular mycorrhiza on uptake of zinc and phosphorus by red clover from a low-phosphorus soil amended with zinc and phosphorus
}

\author{
Y.L. Bi ${ }^{\text {a }}$, X.L. Li ${ }^{\text {a,* }}$, P. Christie ${ }^{\text {a,b }}$ \\ a Department of Plant Nutrition, College of Agricultural Resources and Environmental Sciences, China Agricultural University, \\ Beijing 100094, People's Republic of China \\ ${ }^{\mathrm{b}}$ Department of Agricultural and Environmental Science, Queen's University Belfast, Newforge Lane, Belfast BT9 5 PX, UK
}

\begin{abstract}
In a pot experiment, red clover (Trifolium pratense) was grown in sterilized $\mathrm{Zn}$-amended low available $\mathrm{P}$ soil ( 0,50 or $400 \mathrm{mg} \mathrm{Zn} \mathrm{kg}{ }^{-1}$ ) with or without $100 \mathrm{mg} \mathrm{kg}^{-1}$ added $\mathrm{P}$ and with or without inoculation with the arbuscular mycorrhizal (AM) fungus $G$. mosseae. When the plants were harvested after 40 days, AM colonization of the roots was still at an early stage, with only $14-38 \%$ of total root length colonized on average. AM colonization was highest in low-P soil, and was lowest in soil amended with $400 \mathrm{mg} \mathrm{Zn} \mathrm{kg}^{-1}$. Shoot yields were highest in AM plants with added $\mathrm{P}$, but root yields were unaffected by AM inoculation. Shoot and root yields were higher with $100 \mathrm{mg}$ added $\mathrm{P} \mathrm{kg}^{-1}$ soil, but lower with $400 \mathrm{mg} \mathrm{Zn} \mathrm{kg}^{-1}$ than $50 \mathrm{mg} \mathrm{Zn} \mathrm{kg}{ }^{-1}$ or controls unamended with $\mathrm{Zn}$. Shoot and root $\mathrm{P}$ concentrations were seldom higher in AM plants, but shoot $\mathrm{P}$ offtakes were higher in AM plants with added $\mathrm{P}$.

Concentrations of $\mathrm{Zn}$ and $\mathrm{Cu}$ were much higher in the roots than in the shoots. Shoot and $\operatorname{root} \mathrm{Zn}$ and shoot $\mathrm{Cu}$ were lower, but root $\mathrm{Cu}$ was higher, in $\mathrm{AM}$ plants. Soil residual $\mathrm{pH}$ after plant growth was higher in AM treatments, and residual total $\mathrm{Zn}$ was also higher, indicating lower $\mathrm{Zn}$ uptake by $\mathrm{AM}$ plants. Soil solution $\mathrm{pH}$ was higher in $\mathrm{AM}$ treatments, and soil solution $\mathrm{Zn}$ was lower in the presence of mycorrhiza. The results are discussed in terms of AM protection of the plants against excessive shoot $\mathrm{Zn}$ uptake.
\end{abstract}

(c) 2002 Elsevier Science Ltd. All rights reserved.

Keywords: Arbuscular mycorrhiza; Early colonization; Phosphorus uptake; Zinc uptake; Red clover

\section{Introduction}

Arbuscular mycorrhizal (AM) fungi form ubiquitous symbiotic associations with higher plant roots. These associations have the capability of increasing host plant uptake of immobile elements such as $\mathrm{P}$ and $\mathrm{Zn}$ when they are in short supply (Thompson, 1996), but are also capable of lowering plant uptake of various heavy metals when they are available in excessive quantities in the soil (Leyval et al., 1997; Zhu et al., 2001). The

\footnotetext{
${ }^{*}$ Corresponding author. Tel.: +86-10-6289-1325; fax: +8610-6289-1016.

E-mail address: lixl@mx.cei.gov.cn (X.L. Li).
}

mechanisms involved in decreased uptake of metals by AM plants are largely unknown. Selective (lower) fungal transfer of non-essential metals has been suggested for $\mathrm{Cd}$, as indicated by enhanced root/shoot $\mathrm{Cd}$ ratios in AM plants (Joner and Leyval, 1997). Similarly, Zhu et al. (2001) observed increased immobilization of $\mathrm{Zn}$ in or near the roots of AM white clover with increasing application of $\mathrm{ZnSO}_{4}$ to the soil. The mechanism involved could be direct intracellular precipitation of metal cations with phosphate, or adsorption of metal ions on hyphal walls. Chen et al. (2001), using a glass bead compartment cultivation system, found that $\mathrm{Zn}$ accumulated to concentrations of over $1200 \mathrm{mg} \mathrm{kg}^{-1}$ (dry matter basis) in G. mosseae mycelium associated with maize plants, and Joner et al. (2000) found that excised 
mycelium of several Glomus spp. had large capacities for rapid passive adsorption of $\mathrm{Zn}$ and $\mathrm{Cd}$. $\mathrm{Li}$ and Christie (2001) found that soil solution $\mathrm{Zn}$ concentrations were lower and $\mathrm{pH}$ values were higher in AM red clover than in non-mycorrhizal controls. They suggested that the protective effects of AM inoculation for plants against excessive $\mathrm{Zn}$ uptake may have been due to decreasing $\mathrm{Zn}$ bioavailability in the soil solution or immobilization of $\mathrm{Zn}$ in the host plant roots.

Indirect mechanisms deriving from the effects of AM fungi on rhizosphere properties have also been suggested. These include changes in $\mathrm{pH}$ ( $\mathrm{Li}$ et al., 1991), microbial populations (Olsson et al., 1998) and root exudation patterns (Laheurte et al., 1990). These are all factors known to influence metal mobility or bioavailability.

The objective of the present study was to assess the influence of early stages of AM fungal colonization of red clover on plant growth and $\mathrm{Zn}$ uptake at varying soil zinc concentrations with and without low-P stress.

\section{Materials and methods}

The soil used was a sandy clay loam derived from Silurian shale from a mixed sward of perennial ryegrass
(Lolium perenne L.) and white clover (Trifolium repens L.) in a long-term field experiment at the Agricultural Research Institute of Northern Ireland at Hillsborough, County Down (Irish Grid Reference J244577). Moist samples removed from the top $10 \mathrm{~cm}$ of the soil profile were passed through a $0.5-\mathrm{cm}$ sieve, large stones and plant root debris were removed, and the soil was air dried. The soil contained $50 \mathrm{mg} \mathrm{kg}^{-1}$ 'total' (aqua-regiaextractable) $\mathrm{Zn}$, with $13 \mathrm{mg} \mathrm{kg}^{-1}$ Olsen $\mathrm{P}, 82.7 \mathrm{mg} \mathrm{kg}^{-1}$ exchangeable $\mathrm{K}, 68 \mathrm{mg} \mathrm{kg}^{-1}$ exchangeable $\mathrm{Mg}$ (all oven dry basis), and a $\mathrm{pH}$ (soil:water ratio 1:2.5) value of 5.7 before sterilization. Soil was thoroughly mixed and then sterilized with $10 \mathrm{kGy} \gamma$-radiation using a ${ }^{60} \mathrm{Co}$ source. Sterilized soil (equivalent to $1200 \mathrm{~g}$ oven dried) was placed in $13-\mathrm{cm}$ diameter plastic pots.

Red clover (Trifolium pratense L. cv. Merwe) seeds were surface-sterilized with $10 \%(\mathrm{v} / \mathrm{v}) \mathrm{H}_{2} \mathrm{O}_{2}$ for $10 \mathrm{~min}$ and washed with deionized water. Thirty seeds were sown in each pot on 16 July 1998. There were 12 treatments consisting of three $\mathrm{Zn}$ addition levels (as $\left.\mathrm{Zn}\left(\mathrm{NO}_{3}\right)_{2}\right)$ of 0,50 and $400 \mathrm{mg} \mathrm{Zn} \mathrm{kg}{ }^{-1}$ soil, two added $\mathrm{P}$ levels (as $\mathrm{Ca}\left(\mathrm{H}_{2} \mathrm{PO}_{4}\right)_{2}$ ) of 0 and $100 \mathrm{mg} \mathrm{P} \mathrm{kg}$, and inoculation with the AM fungus $G$. mosseae or uninoculated. The mycorrhizal fungus used was Glomus mosseae which had been propagated on white clover grown in a glasshouse for two months. Colonized root segments and rhizosphere soil were used as inoculum.

Table 1

Mean AM colonization rates, and shoot and root dry matter (DM) yields of mycorrhizal and non-mycorrhizal red clover

\begin{tabular}{|c|c|c|c|c|c|}
\hline Mycorrhizal status & $\begin{array}{l}\text { Added P } \\
\left(\mathrm{mg} \mathrm{kg}^{-1}\right)\end{array}$ & $\begin{array}{l}\text { Added } \mathrm{Zn} \\
\left(\mathrm{mg} \mathrm{kg}^{-1}\right)\end{array}$ & $\begin{array}{l}\text { Root length } \\
\text { colonized }(\%)\end{array}$ & $\begin{array}{l}\text { Shoot yield } \\
\left(\mathrm{gpot}^{-1}\right)\end{array}$ & $\begin{array}{l}\text { Root yield } \\
\left(\mathrm{g} \mathrm{pot}^{-1}\right)\end{array}$ \\
\hline \multirow[t]{6}{*}{ Non-mycorrhizal } & 0 & 0 & $\mathrm{ND}^{\mathrm{a}}$ & 3.1 & 1.16 \\
\hline & & 50 & ND & 2.6 & 0.83 \\
\hline & & 400 & ND & 1.0 & 0.44 \\
\hline & 100 & 0 & ND & 11.8 & 2.14 \\
\hline & & 50 & ND & 12.2 & 2.17 \\
\hline & & 400 & ND & 4.3 & 0.84 \\
\hline \multirow[t]{6}{*}{ Mycorrhizal } & 0 & 0 & 35.0 & 2.0 & 0.68 \\
\hline & & 50 & 38.0 & 2.2 & 0.65 \\
\hline & & 400 & 13.9 & 1.5 & 0.56 \\
\hline & 100 & 0 & 22.3 & 13.4 & 2.15 \\
\hline & & 50 & 15.2 & 13.4 & 1.88 \\
\hline & & 400 & 19.6 & 8.2 & 1.40 \\
\hline \multicolumn{3}{|l|}{ Standard error } & 2.35 & 0.30 & 0.096 \\
\hline \multicolumn{6}{|l|}{ Significance ${ }^{\mathrm{b}}$ due to: } \\
\hline \multicolumn{3}{|l|}{ Mycorrhiza } & ND & $* * *$ & NS \\
\hline \multicolumn{3}{|l|}{ Added P } & $* * *$ & $* * *$ & $* * *$ \\
\hline \multicolumn{3}{|l|}{ Added Zn } & $* * *$ & $* * *$ & $* * *$ \\
\hline \multicolumn{3}{|c|}{ Mycorrhiza $\times$ added $\mathrm{P}$} & ND & $* * *$ & $*$ \\
\hline \multicolumn{3}{|c|}{ Mycorrhiza $\times$ added $\mathrm{Zn}$ rate } & ND & $* * *$ & $* * *$ \\
\hline \multicolumn{3}{|c|}{ Addec $\mathrm{P} \times$ added $\mathrm{Zn}$ rate } & $* * *$ & $* * *$ & $* * *$ \\
\hline \multicolumn{3}{|c|}{ Mycorrhiza $\times$ added $\mathrm{P} \times$ added $\mathrm{Zn}$ rate } & ND & NS & NS \\
\hline
\end{tabular}

${ }^{a} \mathrm{ND}$, not determined (no mycorrhiza observed in uninoculated pots).

${ }^{\mathrm{b}}$ By ANOVA; $* * *, P<0.001 ; * *, P<0.01 ; *, P<0.05 ; \mathrm{NS}$, not significant. 
Mycorrhizal treatments received $13 \mathrm{~g}$ of fresh inoculum, while non-mycorrhizal plants received an equivalent amount of sterilized inoculum together with the filtrate $(0.25 \mu \mathrm{m}$ pore size $)$ of unsterilized soil to provide a similar microflora except for the absence of the mycorrhizal fungus. The inoculum was mixed uniformly with all of the soil in the pot before the seeds were sown. Ten $\mathrm{ml}$ of a suspension of Rhizobium leguminosarum biovar. trifolii were added to each pot to ensure effective nodulation of the roots. There were eight replicates, giving a total of 96 pots.

Mineral nutrients were added in solution to each pot at rates of $300 \mathrm{mg} \mathrm{K}\left(\mathrm{KNO}_{3}\right), 108 \mathrm{mg} \mathrm{N}\left(\mathrm{KNO}_{3}\right)$ and $100 \mathrm{mg} \mathrm{Mg}\left(\mathrm{MgSO}_{4}\right) \mathrm{kg}^{-1}$ soil as a basal application. After 4 weeks of growth, a nitrogen dressing at the rate of $200 \mathrm{mg} \mathrm{N}\left(\mathrm{Ca}\left(\mathrm{NO}_{3}\right)_{2}\right)$ was made to each pot to prevent $\mathrm{N}$ limitation to plant growth. A soil moisture sampler (Rhizon SMS: Rhizosphere Research Products, Doderstraat 62, 6706 JG Wageningen, The Netherlands) was installed in each pot.

Soil moisture was regularly maintained at $70-90 \%$ of field capacity by weight. The experiment was conducted in a glasshouse with a day/night regime of $16 / 8 \mathrm{~h}$ and a temperature regime of $20 / 16^{\circ} \mathrm{C}$. Soil solution samples were taken using the soil moisture samplers on three occasions 12, 23 and 40 days after sowing in order to monitor the $\mathrm{Zn}$ concentration and $\mathrm{pH}$ of the soil solution. The plants were harvested after 40 days of growth. The roots were carefully washed free of soil with tap water, and cut into segments about $1 \mathrm{~cm}$ long. A randomly selected subsample of $1 \mathrm{~g}$ fresh roots from each pot was stained with acid fuchsin and the proportion of root length infected was measured using the gridline intersect method at $\times 200$ magnification with a compound microscope. The weights of shoots and bulk roots were determined after drying at $70{ }^{\circ} \mathrm{C}$ for $48 \mathrm{~h}$. Subsamples of roots and shoots were ground to pass a 0.5 $\mathrm{mm}$ sieve and dry ashed at $500{ }^{\circ} \mathrm{C}$ for mineral nutrient analysis. Plant $\mathrm{P}$ was determined colorimetrically, and $\mathrm{Zn}$ by atomic absorption spectroscopy using standard methods (Ministry of Agriculture, Fisheries and Food, 1986). Other elements were analysed by inductively coupled plasma-atomic emission spectroscopy (ICPAES). Soil $\mathrm{pH}$, Olsen $\mathrm{P}$, exchangeable $\mathrm{K}$ and aquaregia-extractable $\mathrm{Zn}$ and $\mathrm{Cu}$ (with ICP-AES) were determined on samples of the residual soil after plant growth. Soil solution samples were analysed for $\mathrm{pH}$ and for $\mathrm{Zn}$ using ICP-AES.

Table 2

Mean concentrations and offtakes of $\mathrm{P}, \mathrm{Zn}$ and $\mathrm{Cu}$ in shoots of mycorrhizal and non-mycorrhizal red clover

\begin{tabular}{|c|c|c|c|c|c|c|c|}
\hline \multirow{2}{*}{$\begin{array}{l}\text { Added P } \\
\left(\mathrm{mg} \mathrm{kg}^{-1}\right)\end{array}$} & \multirow{2}{*}{$\begin{array}{l}\text { Added } \mathrm{Zn} \\
\left(\mathrm{mg} \mathrm{kg}^{-1}\right)\end{array}$} & \multicolumn{3}{|c|}{ Shoot concentration } & \multicolumn{3}{|c|}{ Shoot offtake } \\
\hline & & $\begin{array}{l}\mathrm{P} \\
(\%)\end{array}$ & $\begin{array}{l}\mathrm{Zn} \\
\left(\mathrm{mg} \mathrm{kg}^{-1}\right)\end{array}$ & $\begin{array}{l}\mathrm{Cu} \\
\left(\mathrm{mg} \mathrm{kg}^{-1}\right)\end{array}$ & $\begin{array}{l}\mathrm{P} \\
\left(\mathrm{mg} \mathrm{pot}^{-1}\right)\end{array}$ & $\begin{array}{l}\mathrm{Zn} \\
\left(\mu \mathrm{g} \mathrm{pot}^{-1}\right)\end{array}$ & $\begin{array}{l}\mathrm{Cu} \\
\left(\mu \mathrm{g} \mathrm{pot}^{-1}\right)\end{array}$ \\
\hline \multicolumn{8}{|l|}{ Non-mycorrhizal } \\
\hline \multirow[t]{3}{*}{0} & 0 & 0.10 & 19 & 17.5 & 3.2 & 59 & 55 \\
\hline & 50 & 0.10 & 122 & 18.5 & 2.6 & 316 & 48 \\
\hline & 400 & 0.11 & 1430 & 26.1 & 1.1 & 1462 & 28 \\
\hline \multirow[t]{3}{*}{100} & 0 & 0.23 & 17 & 12.0 & 27.2 & 191 & 142 \\
\hline & 50 & 0.23 & 73 & 15.9 & 28.2 & 894 & 194 \\
\hline & 400 & 0.29 & 1418 & 33.9 & 12.5 & 6165 & 148 \\
\hline \multicolumn{8}{|l|}{ Mycorrhizal } \\
\hline \multirow[t]{3}{*}{0} & 0 & 0.13 & 27 & 16.0 & 2.6 & 52 & 32 \\
\hline & 50 & 0.11 & 44 & 16.8 & 2.5 & 98 & 38 \\
\hline & 400 & 0.10 & 632 & 23.6 & 1.5 & 964 & 37 \\
\hline \multirow[t]{3}{*}{100} & 0 & 0.22 & 13 & 11.3 & 29.8 & 167 & 150 \\
\hline & 50 & 0.22 & 32 & 13.4 & 29.2 & 423 & 182 \\
\hline & 400 & 0.24 & 461 & 15.8 & 19.3 & 3728 & 127 \\
\hline Standard error & & 0.006 & 30.7 & 2.58 & 0.65 & 150.4 & 15.2 \\
\hline \multicolumn{8}{|l|}{ Significance ${ }^{a}$ due to: } \\
\hline Mycorrhiza & & $*$ & $* * *$ & $* *$ & $* * *$ & $* * *$ & NS \\
\hline Added P & & $* * *$ & * & NS & $* * *$ & $* * *$ & $* * *$ \\
\hline Added $\mathrm{Zn}$ & & $* * *$ & $* * *$ & $* * *$ & $* * *$ & $* * *$ & $*$ \\
\hline Mycorrhiza $\times$ added $\mathrm{P}$ & & $* * *$ & NS & NS & $* * *$ & $* * *$ & NS \\
\hline Mycorrhiza $\times \mathrm{Zn}$ rate & & $* * *$ & $* * *$ & $*$ & $* *$ & $* * *$ & NS \\
\hline Added $\mathrm{P} \times \mathrm{Zn}$ rate & & $* * *$ & NS & NS & $* * *$ & $* * *$ & NS \\
\hline Mycorrhiza $\times$ added $\mathrm{P} \times \mathrm{Zn}$ rate & & NS & NS & NS & $*$ & $* * *$ & NS \\
\hline
\end{tabular}

\footnotetext{
${ }^{\mathrm{a}}$ By analysis of variance; $* * *, P<0.001 ; * *, P<0.01 ; *, P<0.05$; NS, not significant.
} 
Data were subjected to analysis of variance (ANOVA) using the GENSTAT package (GENSTAT Committee, 1994). Soil solution $\mathrm{pH}$ and $\mathrm{Zn}$ concentrations were tested by repeated measures ANOVA to compare the three sampling occasions.

\section{Results}

No AM colonization was observed in any of the uninoculated control pots. The highest colonization rates (35-38\% of root length) occurred in the absence of added $P$ with no $\mathrm{Zn}$ addition or $50 \mathrm{mg}$ added $\mathrm{Zn} \mathrm{kg}{ }^{-1}$ soil (Table 1). The highest application rate of $\mathrm{Zn}$ lowered colonization to only $14 \%$. Except at the highest $\mathrm{Zn}$ application rate, addition of $\mathrm{P}$ decreased AM colonization. Shoot yield was increased by AM but root yield was unaffected (Table 1). Shoot and root yields were depressed by the highest application rate of $\mathrm{Zn}$.

Shoot and root $\mathrm{P}$ and $\mathrm{Zn}$ concentrations were lowered by AM colonization (Tables 2 and 3), and were increased by the high application rate of $\mathrm{Zn}$. Shoot $\mathrm{Cu}$ showed similar trends, but root $\mathrm{Cu}$ concentrations were increased by AM and decreased with increasing $\mathrm{Zn}$ application rate. Shoot $\mathrm{P}$ offtakes were increased by AM with added P, but root offtakes were decreased by AM. Both shoot and root $\mathrm{Zn}$ offtakes were decreased by AM. Shoot $\mathrm{Cu}$ offtakes were unaffected by AM, but root offtakes increased with AM colonization. Root concentrations of $\mathrm{Zn}$ and $\mathrm{Cu}$ were much higher than shoot concentrations (Tables 2 and 3).

At the end of the experiment, residual soil $\mathrm{pH}$ was higher in AM treatments (6.1 on average) than in controls ( $\mathrm{pH}$ 5.5) (Table 4), and soil solution $\mathrm{pH}$ was higher in AM pots than in non-mycorrhizal controls during plant growth (Table 5). Soil and soil solution $\mathrm{pH}$ decreased with increasing $\mathrm{Zn}$ application rate.

Residual soil Olsen $\mathrm{P}$ was lower in AM pots (27 vs. 31 on average), but there was no AM effect on residual soil exchangeable $\mathrm{K}$ (Table 4). Residual soil total $\mathrm{Zn}$ was higher in $\mathrm{AM}$ pots, but total $\mathrm{Cu}$ was unaffected by $\mathrm{AM}$ colonization. Soil solution $\mathrm{Zn}$ was consistently lower in AM pots than in non-mycorrhizal controls throughout the experiment, and was unaffected by added $\mathrm{Zn}$ (Table 5).

Table 3

Mean concentrations and offtakes of $\mathrm{P}, \mathrm{Zn}$ and $\mathrm{Cu}$ in roots of mycorrhizal and non-mycorrhizal red clover

\begin{tabular}{|c|c|c|c|c|c|c|c|}
\hline \multirow{2}{*}{$\begin{array}{l}\text { Added P } \\
\left(\mathrm{mg} \mathrm{kg}^{-1}\right)\end{array}$} & \multirow{2}{*}{$\begin{array}{l}\text { Added } \mathrm{Zn} \\
\left(\mathrm{mg} \mathrm{kg}^{-1}\right)\end{array}$} & \multicolumn{3}{|c|}{ Root concentration } & \multicolumn{3}{|c|}{ Root offtake } \\
\hline & & $\begin{array}{l}\mathrm{P} \\
(\%) \\
\end{array}$ & $\begin{array}{l}\mathrm{Zn} \\
\left(\mathrm{mg} \mathrm{kg}^{-1}\right)\end{array}$ & $\begin{array}{l}\mathrm{Cu} \\
\left(\mathrm{mg} \mathrm{kg}^{-1}\right)\end{array}$ & $\begin{array}{l}\mathrm{P} \\
\left(\mathrm{mg} \mathrm{pot}^{-1}\right)\end{array}$ & $\begin{array}{l}\mathrm{Zn} \\
\left(\mu \mathrm{g} \mathrm{pot}^{-1}\right)\end{array}$ & $\begin{array}{l}\mathrm{Cu} \\
\left(\mu \mathrm{g} p o t^{-1}\right)\end{array}$ \\
\hline \multicolumn{8}{|l|}{ Non-mycorrhizal } \\
\hline \multirow[t]{3}{*}{0} & 0 & 0.13 & 93 & 84 & 1.5 & 108 & 95 \\
\hline & 50 & 0.13 & 948 & 50 & 1.1 & 768 & 42 \\
\hline & 400 & 0.16 & 9791 & 51 & 0.7 & 4395 & 18 \\
\hline \multirow[t]{3}{*}{100} & 0 & 0.36 & 107 & 68 & 7.7 & 222 & 145 \\
\hline & 50 & 0.36 & 621 & 60 & 7.7 & 1350 & 128 \\
\hline & 400 & 0.44 & 8991 & 63 & 3.7 & 7488 & 53 \\
\hline \multicolumn{8}{|l|}{ Mycorrhizal } \\
\hline \multirow[t]{3}{*}{0} & 0 & 0.15 & 200 & 117 & 1.0 & 130 & 74 \\
\hline & 50 & 0.15 & 377 & 98 & 1.0 & 242 & 63 \\
\hline & 400 & 0.14 & 4101 & 79 & 0.8 & 2162 & 49 \\
\hline \multirow[t]{3}{*}{100} & 0 & 0.29 & 91 & 101 & 6.1 & 206 & 230 \\
\hline & 50 & 0.29 & 313 & 83 & 5.5 & 586 & 154 \\
\hline & 400 & 0.32 & 3756 & 85 & 4.5 & 5230 & 122 \\
\hline Standard error & & 0.007 & 302.1 & 10.0 & 0.26 & 273.1 & 19.3 \\
\hline \multicolumn{8}{|l|}{ Significance $^{\mathrm{a}}$ due to: } \\
\hline Mycorrhiza & & $* * *$ & $* * *$ & $* * *$ & $* * *$ & $* * *$ & ** \\
\hline Added P & & $* * *$ & NS & NS & $* * *$ & $* * *$ & $* * *$ \\
\hline Added $\mathrm{Zn}$ & & $* * *$ & $* * *$ & $* *$ & $* * *$ & $* * *$ & $* * *$ \\
\hline Mycorrhiza $\times$ added $\mathrm{P}$ & & $* * *$ & NS & NS & $* *$ & NS & * \\
\hline Mycorrhiza $\times \mathrm{Zn}$ rate & & $* * *$ & $* * *$ & NS & $* * *$ & $* * *$ & NS \\
\hline Added $\mathrm{P} \times \mathrm{Zn}$ rate & & $* * *$ & NS & NS & $* * *$ & $* * *$ & NS \\
\hline Mycorrhiza $\times$ added $\mathrm{P} \times \mathrm{Zn}$ rate & & NS & NS & NS & $* * *$ & NS & NS \\
\hline
\end{tabular}

${ }^{\mathrm{a}}$ By analysis of variance; $* * *, P<0.001 ; * *, P<0.01 ; *, P<0.05$; NS, not significant. 
Table 4

Residual soil analysis after plant harvest

\begin{tabular}{|c|c|c|c|c|c|c|}
\hline $\begin{array}{l}\text { Added P } \\
\left(\mathrm{mg} \mathrm{kg}^{-1}\right)\end{array}$ & $\begin{array}{l}\text { Added } \mathrm{Zn} \\
\left(\mathrm{mg} \mathrm{kg}^{-1}\right)\end{array}$ & $\begin{array}{l}\mathrm{pH} \\
\text { (units) }\end{array}$ & $\begin{array}{l}\text { Olsen P } \\
\left(\mathrm{mg} \mathrm{kg}^{-1}\right)\end{array}$ & $\begin{array}{l}\text { Exch. K } \\
\left(\mathrm{mg} \mathrm{kg}^{-1}\right)\end{array}$ & $\begin{array}{l}\text { Total Zn } \\
\left(\mathrm{mg} \mathrm{kg}^{-1}\right)\end{array}$ & $\begin{array}{l}\text { Total } \mathrm{Cu} \\
\left(\mathrm{mg} \mathrm{kg}^{-1}\right)\end{array}$ \\
\hline \multicolumn{7}{|l|}{ Non-mycorrhizal } \\
\hline \multirow[t]{3}{*}{0} & 0 & 5.6 & 12 & 57 & 35 & 7.7 \\
\hline & 50 & 5.3 & 13 & 68 & 99 & 7.6 \\
\hline & 400 & 5.3 & 12 & 146 & 432 & 7.3 \\
\hline \multirow[t]{3}{*}{100} & 0 & 5.7 & 48 & 17 & 34 & 7.1 \\
\hline & 50 & 5.7 & 47 & 18 & 93 & 7.4 \\
\hline & 400 & 5.3 & 52 & 55 & 432 & 7.6 \\
\hline \multicolumn{7}{|l|}{ Mycorrhizal } \\
\hline \multirow[t]{3}{*}{0} & 0 & 6.1 & 10 & 84 & 37 & 7.9 \\
\hline & 50 & 6.2 & 10 & 74 & 111 & 7.8 \\
\hline & 400 & 5.9 & 10 & 120 & 471 & 7.5 \\
\hline \multirow[t]{3}{*}{100} & 0 & 6.3 & 45 & 18 & 34 & 6.9 \\
\hline & 50 & 6.2 & 44 & 17 & 102 & 7.6 \\
\hline & 400 & 6.0 & 46 & 29 & 432 & 7.2 \\
\hline Standard error & & 0.03 & 0.6 & 5.6 & 5.2 & 0.18 \\
\hline \multicolumn{7}{|l|}{ Significance ${ }^{\mathrm{a}}$ due to: } \\
\hline Mycorrhiza & & $* * *$ & $* * *$ & NS & $* * *$ & NS \\
\hline Added P & & $* * *$ & $* * *$ & $* * *$ & $* *$ & $* *$ \\
\hline Zn rate & & $* * *$ & $* * *$ & $* * *$ & $* * *$ & NS \\
\hline Mycorrhiza $\times$ added $\mathrm{P}$ & & NS & $* *$ & NS & * & NS \\
\hline Mycorrhiza $\times \mathrm{Zn}$ rate & & $* * *$ & NS & $* * *$ & NS & NS \\
\hline Added $\mathrm{P} \times \mathrm{Zn}$ rate & & NS & $* * *$ & $* * *$ & NS & $* *$ \\
\hline Mycorriza $\times \mathrm{P} \times \mathrm{Zn}$ & & $* * *$ & NS & NS & $*$ & NS \\
\hline
\end{tabular}

${ }^{\mathrm{a}}$ By analysis of variance; $* * *, P<0.001 ; * *, P<0.01 ; *, P<0.05$; NS, not significant.

\section{Discussion}

In general, our present results agree with those of $\mathrm{Li}$ and Christie (2001), who studied AM red clover under similar conditions. For example, the decreased plant uptake of $\mathrm{Zn}$, and lower concentrations of $\mathrm{Zn}$ and higher $\mathrm{pH}$ values in the soil solution of AM pots are in agreement. However, some of the results differ, and this may be related to differences in the experimental conditions. Firstly, Li and Christie (2001) used threecompartment pots ('rhizoboxes'). The plants grew in a central compartment separated by $30-\mu \mathrm{m}$-mesh barriers from the two outer compartments. Extraradical hyphae (but not plant roots) could penetrate into the outer compartments, and the $\mathrm{Zn}$ applications were made to one of the outer compartments. The highest $\mathrm{Zn}$ addition was $1000 \mathrm{mg} \mathrm{kg}^{-1}$, but only the external mycelium of the AM pots could penetrate the soil containing the added $\mathrm{Zn}$. As a consequence, there was no significant depression of plant yield by applied $\mathrm{Zn}$, even at an application rate of $1000 \mathrm{mg} \mathrm{kg}^{-1}$. In contrast, in the present study, the roots of the plants were exploiting the same single soil volume as the external mycelium. Our results show that plant yields were depressed by application of 400 $\mathrm{mg} \mathrm{Zn} \mathrm{kg}{ }^{-1}$. In fact, application of $1000 \mathrm{mg} \mathrm{Zn} \mathrm{kg}^{-1}$ was included as a treatment in the present experiment, but all of the seedlings (both AM and non-mycorrhizal) died in this high-Zn treatment and the treatment has not been included in this paper. On the other hand, Zhu et al. (2001) grew white clover plants in the same soil mixed with sand and amended with various rates of $\mathrm{Zn}$ up to $400 \mathrm{mg} \mathrm{kg}^{-1}$. The highest application rate led to a small decrease $(P<0.05)$ in plant yield, but the plants had grown for 20 weeks, three times longer than in the present study. Thus, on balance it would seem that we can interpret our plant growth responses to applied $\mathrm{Zn}$ as responses of young plants at an early stage of AM colonization.

One new aspect investigated in the present work was the chemical analysis of the residual soil in the pots after plant growth. The higher residual soil $\mathrm{pH}$ observed in the AM treatments agrees with the higher soil solution $\mathrm{pH}$ values noted by $\mathrm{Li}$ and Christie (2001). The lower plant-available $\mathrm{P}$ found in the AM pots also supports the higher $\mathrm{P}$ offtakes detected, and the higher residual soil total $\mathrm{Zn}$ measured in the AM pots is in accord with the lower $\mathrm{Zn}$ uptakes observed in AM plants. Thus, the AM fungus seems to protect the host plant from moderate $\mathrm{Zn}$ pollution by immobilizing $\mathrm{Zn}$ in the mycelium. This may lower soil solution $\mathrm{Zn}$ concentrations, lower 
Table 5

Mean soil solution $\mathrm{pH}$ and $\mathrm{Zn}$ concentration on three sampling occasions during the growth of AM and non-mycorrhizal red clover

\begin{tabular}{|c|c|c|c|c|c|c|c|}
\hline \multirow{2}{*}{$\begin{array}{l}\text { Added } \mathrm{Zn} \\
\left(\mathrm{mg} \mathrm{kg}^{-1}\right)\end{array}$} & \multirow{2}{*}{$\begin{array}{l}\text { Added P } \\
\left(\mathrm{mg} \mathrm{kg}^{-1}\right)\end{array}$} & \multicolumn{3}{|l|}{$\mathrm{pH}$} & \multicolumn{3}{|c|}{$\mathrm{Zn}\left(\mathrm{mgl}^{-1}\right)$} \\
\hline & & 28 July & 8 Aug & $28 \mathrm{Aug}$ & 28 July & 8 Aug & 28 Aug \\
\hline \multicolumn{8}{|l|}{ Non-mycorrhizal } \\
\hline \multirow[t]{3}{*}{0} & 0 & 6.6 & 6.5 & 5.8 & 0.2 & 0.1 & 0.2 \\
\hline & 50 & 6.1 & 5.8 & 5.2 & 1.9 & 3.2 & 4.6 \\
\hline & 400 & 5.4 & 5.6 & 5.4 & 77.8 & 80.2 & 91.6 \\
\hline \multirow[t]{3}{*}{100} & 0 & 6.4 & 5.4 & 6.7 & 0.3 & 0.7 & 0.2 \\
\hline & 50 & 6.0 & 5.2 & 6.6 & 2.3 & 5.5 & 1.1 \\
\hline & 400 & 5.5 & 5.3 & 5.5 & 59.6 & 105.1 & 83.1 \\
\hline \multicolumn{8}{|l|}{ Mycorrhizal } \\
\hline \multirow[t]{3}{*}{0} & 0 & 6.8 & 6.7 & 6.4 & 0.2 & 0.3 & 0.2 \\
\hline & 50 & 6.8 & 6.8 & 6.5 & 0.4 & 0.6 & 0.7 \\
\hline & 400 & 6.3 & 6.6 & 6.3 & 31.4 & 26.4 & 40.4 \\
\hline \multirow[t]{3}{*}{100} & 0 & 7.0 & 6.9 & 6.6 & 0.9 & 0.3 & 0.2 \\
\hline & 50 & 6.9 & 6.9 & 6.8 & 0.4 & 1.4 & 0.4 \\
\hline & 400 & 6.3 & 6.5 & 6.8 & 30.6 & 58.0 & 7.1 \\
\hline Standard error & & & 0.03 & & & 1.78 & \\
\hline \multicolumn{8}{|l|}{ Significance ${ }^{\mathrm{a}}$} \\
\hline Mycorrhiza & & & $* * *$ & & & $* * *$ & \\
\hline $\mathrm{Zn}$ rate & & & $* * *$ & & & $* *$ & \\
\hline $\mathrm{P}$ rate & & & $* *$ & & & NS & \\
\hline Date & & & $* *$ & & & $* *$ & \\
\hline Myc $\times$ added $P$ & & & NS & & & NS & \\
\hline Myc $\times$ added $\mathrm{Zn}$ rate & & & $* * *$ & & & $* * *$ & \\
\hline $\mathrm{Myc} \times \mathrm{P} \times \mathrm{Zn}$ rate & & & NS & & & NS & \\
\hline
\end{tabular}

${ }^{\mathrm{a}}$ By analysis of variance; $* * *, P<0.001 ; * *, P<0.01 ; *, P<0.05 ; \mathrm{NS}$, not significant.

root and shoot $\mathrm{Zn}$ concentrations, and leave more residual $\mathrm{Zn}$ in the soil.

Another difference between Li and Christie's (2001) experiment and the present work is the shorter growth period in the present experiment (40 vs. 63 days). We attribute the lower AM colonization rates in the present experiment to the shorter plant growth period. However, we cannot be certain that our results reflect an earlier stage of AM colonization. Because the roots of the plants were exploiting the same soil compartment as were the external hyphae (as noted above), we cannot be sure that the lower colonization rates found in the highest added $\mathrm{Zn}$ treatment would not persist if the experiment were continued until 60 days as a result of $\mathrm{Zn}$ toxicity to the roots. This aspect requires further investigation.

\section{Conclusions}

Our results are consistent with the suggestion (Chen et al., 2001; Li and Christie, 2001; Zhu et al., 2001) that AM fungi immobilize heavy metals such as $\mathrm{Zn}$ in moderately polluted soils. This decreases soil solution $\mathrm{Zn}$ concentration and root and shoot $\mathrm{Zn}$ uptake, and increases residual $\mathrm{Zn}$ remaining in the soil after plant growth. This is in contrast to their tendency to decrease residual soil available $\mathrm{P}$ in low-P soils. The fungi increase soil $\mathrm{pH}$, and this could also contribute to lower plant $\mathrm{Zn}$ uptake by making soil $\mathrm{Zn}$ less bioavailable. Joner et al. (2000) showed that excised mycelium of several Glomus spp. previously exposed to heavy metals had rapid and high metal-binding capacities. Use of metabolic inhibitors indicated that fungal sorption of metals was passive. However, AM fungi can also increase plant uptake of soil trace metal nutrients (such as $\mathrm{Zn}$ and $\mathrm{Cu}$ ) when these are in short supply. There remains the question of which mechanisms are involved in enhanced plant trace metal nutrition.

\section{Acknowledgements}

We thank the Major State Basic Research Development Programme of the People's Republic of China (Project G1999011808), the National Natural Science Foundation of China (Project 40071050), the Laboratory of Material Cycling in Pedosphere, Institute of Soil Science, Chinese Academy of Sciences, the Royal 
Society and the British Council (Project PEK/0992/314) for generous financial support. Ms E.A. Wasson gave excellent technical assistance and Dr David J. Kilpatrick, Biometrics Department, Queen's University Belfast, performed the statistical analysis of the data.

\section{References}

Chen, B.D., Christie, P., Li, X.L., 2001. A modified glass bead compartment cultivation system for studies on nutrient and trace metal uptake by arbuscular mycorrhiza. Chemosphere 42, 185-192.

GENSTAT Committee, 1994. GENSTAT 5 Reference Manual. Clarendon Press, Oxford.

Joner, E.J., Leyval, C., 1997. Uptake of ${ }^{109} \mathrm{Cd}$ by roots and hyphae of a Glomus mosseae/Trifolium subterraneum mycorrhiza from soil amended with high and low concentrations of cadmium. New Phytol. 135, 353-360.

Joner, E.J., Briones, R., Leyval, C., 2000. Metal-binding capacity of arbuscular mycorrhizal mycelium. Plant Soil 226, 227-234.

Laheurte, F., Leyval, C., Berthelin, J., 1990. Root exudates of maize, pine and beech seedlings influenced by mycorrhizal and bacterial inoculation. Symbiosis 9, 111-116.
Leyval, C., Turnau, K., Haselwandter, K., 1997. Effect of heavy metal pollution on mycorrhizal colonization and function: physiological, ecological and applied aspects. Mycorrhiza 7, 139-153.

Li, X.L., Christie, P., 2001. Changes in soil solution $\mathrm{Zn}$ and $\mathrm{pH}$ and uptake of $\mathrm{Zn}$ by arbuscular mycorrhizal red clover in Zn-contaminated soil. Chemosphere 42, 201-207.

Li, X.L., George, E., Marschner, H., 1991. Phosphorus depletion and $\mathrm{pH}$ decrease at the root-soil and hyphaesoil interfaces of VA mycorrhizal white clover fertilized with ammonium. New Phytol. 119, 397-404.

Ministry of Agriculture, Fisheries and Food, 1986. The Analysis of Agricultural Materials. In: Reference Book 427, third ed. HMSO, London.

Olsson, P.A., Francis, R., Read, D.J., Söderström, B., 1998. Growth of arbuscular mycorrhizal mycelium in calcareous dune sand and its interaction with other soil microorganisms as estimated by measurement of specific fatty acids. Plant Soil 201, 9-16.

Thompson, J.P., 1996. Correction of dual phosphorus and zinc deficiencies of linseed (Linum usitatissimum L.) with cultures of vesicular-arbuscular mycorrhizal fungi. Soil Biol. Biochem. 28, 941-951.

Zhu, Y.G, Christie, P., Laidlaw, A.S., 2001. Uptake of Zn by arbuscular mycorrhizal white clover from $\mathrm{Zn}$-contaminated soil. Chemosphere 42, 193-199. 